\title{
Organozinc Reagents for Facile Synthetic Route to Diflunisal, Fenbufen and Felbinac
}

\author{
Seung-Hoi Kim and Jong-Gyu Kim* \\ Department of Chemistry, Dankook University, Cheonan 330-714 Korea.*E-mail: jkim16@dankook.ac.kr \\ Received October 21, 2010, Accepted November 10, 2010
}

Key Words: Coupling reaction, Organozinc, Diflunisal, Fenbufen, Felbinac

Of many organometallics, organozinc reagents have been found to be an excellent reagent for the cross-coupling reactions mainly due to the compatible functional group tolerance. More significantly, most of the organozinc reagents are easily prepared by either the direct insertion of zinc metal or transmetallation with zinc salts. ${ }^{1}$

In our continuing study on the preparation and application of organozinc reagents, ${ }^{2}$ we have found that several organozinc reagents undergo the cross-coupling reactions with the appropriate coupling partners to give rise to the biologically active compounds under mild conditions. Herein, we would like to report our preliminary results of the preparation of some nonsteroidal anti-inflammatory drugs (NSAIDs) using readily available organozinc reagents.

\section{Results and Discussion}

Preparation of 2',4'-Difluoro-4-hydroxybiphenyl-3-carboxylic Acid (Diflunisal). Diflunisal is a nonacetylated phenylderivative of salicylic acid and shows analgesic and antipyretic effects. And also, it is more effective in hyperestesia assay and adjuvant arthritis than Aspirin. ${ }^{3}$ There are two synthetic approaches to the preparation of Diflunisal; a conventional method consisting of multi-step synthesis ${ }^{4}$ and a catalytic method utilizing metal-catalyzed coupling reaction of organometallics. ${ }^{5}$ Recently, the catalytic methods requiring less steps are more actively investigated because it is more efficient in large scale production. Among those, Suzuki coupling reaction is frequently used under several different reaction conditions. ${ }^{6}$ Even though the present Negishi coupling using an iodoaryl compound for the synthesis of organozinc has been developed, ${ }^{7}$ there is still a need to explore a more facile route for the preparation of Diflunisal. Significantly, it should be emphasized that the organozinc reagents used in our study were prepared using a bromoaryl compound which would be of benefit on large scale. To our best knowledge, it is the first attempt using a bromoaryl compound for the preparation of the corresponding organozinc reagent.

As described in Scheme 1, 2,4-difluorophenylzinc bromide (1) was easily prepared by the reaction of highly active zinc $(\mathrm{Zn} *){ }^{8}$ The following subsequent coupling reaction of 1 with methyl 2-hydroxy-5-bromobenzoate was carried out in the presence of $2 \mathrm{~mol} \% \mathrm{Pd}(\mathrm{OAc})_{2}$ and $4 \mathrm{~mol} \% \mathrm{SPhos}$ in THF at rt. The cross-coupling product (1a) was obtained in $95 \%$ isolated yield. For the coupling reaction, $\mathrm{Pd}\left(\mathrm{PPh}_{3}\right)_{2} \mathrm{Cl}_{2}$ was also attempted but no advantage was found. A typical hydrolysis resulted in the formation of Diflunisal (1b) in 90\% isolated yield.

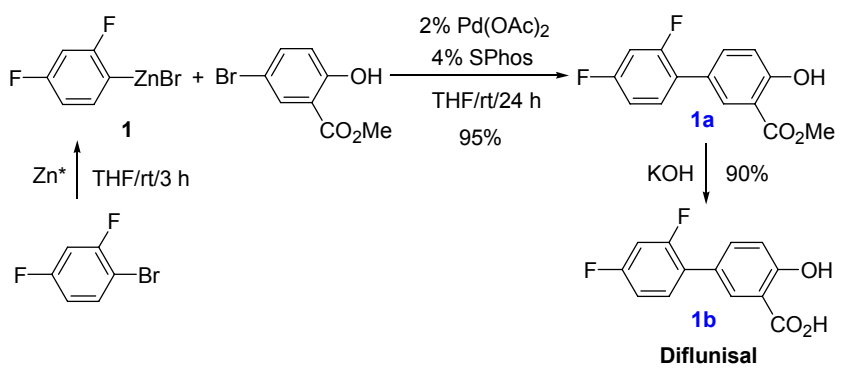

Scheme 1. Preparation of Diflunisal

Preparation of 4-(Biphenyl-4-yl)-4-oxobutanoic Acid (Fenbufen). With the aforementioned encouraging result, we have investigated the preparation of $\gamma$-oxobenzenebutanoic acid derivatives. Due to the significant role in many pharmaceutically active compounds such as Fenbufen, Bucloxic acid, Trepibutanone, and Menbutone. ${ }^{9}$ we are especially interested in Fenbufen. Fenbufen is another NSAID used mainly for pain reliever. For the preparation of Fenbufen, Friedel-Crafts acylation with succinic anhydride is the most frequently used even on a large scale production. ${ }^{10}$ Generally this procedure involves the use of high molar equivalents of aluminum chloride and a tedious workup/purification procedure. Although several methods of preparing Fenbufen have been developed, these limitations have led to the development of facile synthetic procedures.

In our study, a simple cross-coupling reaction of readily available organozinc reagents has been applied to the synthesis of Fenbufen. As depicted in Scheme 2, utilizing either 4-biphenylzinc bromide (2) or 3-ethoxy-3-oxopropylzinc bromide (3) provided an alternative synthetic route for the preparation of Fenbufen (2b). To this end, we have developed two different approaches; coupling reactions of $\mathbf{2}$ with ethyl succinyl chloride (route $\mathbf{A}$ ), and $\mathbf{3}$ with biphenyl-4-carbonyl chloride (route $\mathbf{B}$ ). Widely-employed catalysts such as $\mathrm{Pd}\left(\mathrm{PPh}_{3}\right)_{4}$ and $\mathrm{CuI} / \mathrm{LiCl}$ in

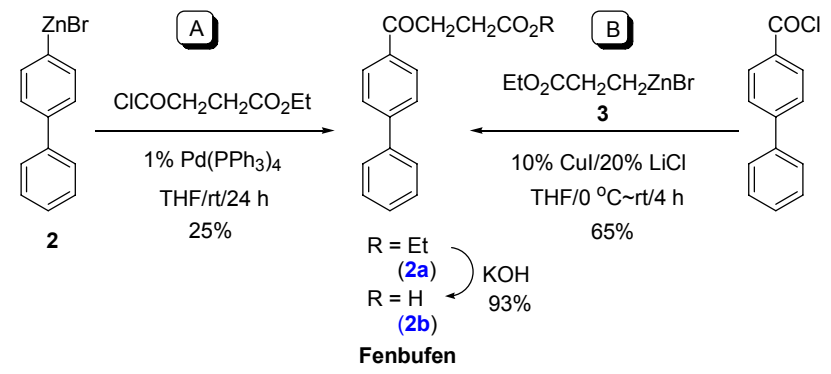

Scheme 2. Preparation of Fenbufen 
the cross-coupling reaction of organozinc chemistry were examined first in route A. A very interesting result was observed in the coupling reactions. As depicted in Scheme 2, Pd-catalyst turned out to be more efficient to give rise to the coupling product (2a). Low isolated yield (25\%) was due to the formation of a by-product, which was obtained from a side reaction of an acid chloride with the solvent (THF) used in this reaction. ${ }^{11}$ In the presence of $\mathrm{Cu}$-catalyst, a severe limitation producing more by-products was found in this coupling reaction (rout $\mathbf{A}$ ). In contrast, copper-catalyzed cross-coupling reaction of $\mathbf{3}$ with biphenyl-4-carbonyl chloride underwent successfully and lead to the formation of coupling product (2a) in moderate isolated yield (65\%). A similar coupling reaction was also carried out between 3 and biphenyl-4-carbonyl chloride in the presence of a catalytic amount of $\mathrm{Pd}\left(\mathrm{PPh}_{3}\right)_{4}$. Unfortunately, no coupling product was resulted. Conversion of the resulting ester (2a) to the corresponding acid was easily completed by a simple hydrolysis affording Fenbufen (2b) in 93\% yield.

Preparation of 2-(Biphenyl-4-yl)acetic Acid (Felbinac). Unlike other alkyl or aryl organometallics, the preparation of benzylmetallic reagents is always challenging mainly because of the formation of homo-coupling product. A limited number of studies on the preparation and application of benzyl organometallic reagents have been reported. ${ }^{12}$ Benzylzinc halide used in our study was readily prepared by the direct insertion of active zinc into benzyl chloride in THF at $0{ }^{\circ} \mathrm{C}$. Resulting organozinc (4) was directly applied to the preparation of 2-(biphenyl-4-yl) acetic acid known as Felbinac (3b), which has been used as a pharmaceutically active compound, especially useful on reducing transient ischemic attacks of the brain and possibly the heart as well as in preventing the clothing of shed blood. ${ }^{13}$ Even though Suzuki coupling reaction has been widely explored for the preparation of $\mathbf{3 b},{ }^{14}$ to our best knowledge, there is no report of using benzylzinc halide for the preparation of Felbinac. During our investigation for the application of benzylzinc halides, we found that ethyl chloroformate was successfully coupled with 4-phenylbenzylzinc chloride (4) in the presence of $1 \% \mathrm{Pd}\left(\mathrm{PPh}_{3}\right)_{4}$ in THF affording the corresponding coupling product 3a in 67\% isolated yield. Copper-catalyst also was employed in this coupling reaction but no reaction took place. It should be mentioned that most of the present methods for the preparation of biaryl acetic acids have been accomplished by the construction of $\mathrm{C}_{\mathrm{sp} 2}-\mathrm{C}_{\mathrm{sp} 2}$ bond forming reaction. It is of special interest that the acidic functionality has been introduced by the direct coupling reaction of benzylzinc and ethyl chloroacetate. A drawback to this procedure was the formation of small amount (less than 10\%) of homo-coupling product of the organozinc reagent. Again, a simple hydrolysis provided 2-(biphenyl-4-yl)acetic acid $\mathbf{3 b}$ in $94 \%$ yield.

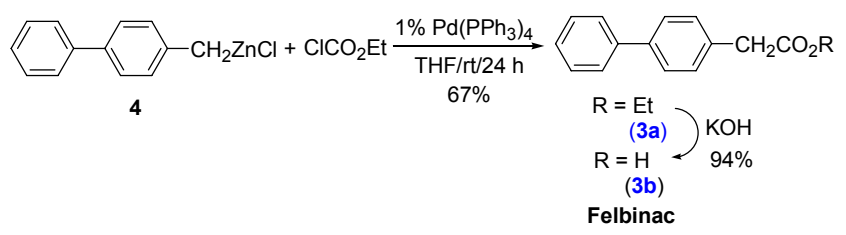

Scheme 3. Preparationof Felbinac
In conclusion, a practical synthetic procedure for the preparation of NSAIDs such as Diflunisal, Fenbufen, and Felbinac has been revealed via the cross-coupling reaction of organozinc reagents. Significantly, organozinc reagents used in this study have been prepared using readily available aryl halides. It is also of interest that the preparation of organozinc halides and their subsequent coupling reactions have been performed under mild conditions. More importantly, this protocol could provide another synthetic strategy for the preparation of a wide range of biaryl functionalities that are interested in a number of bioactive molecules. Further applications of this methodology are currently under investigation.

\section{Experimental Section}

Preparation of Highly Active Zinc. To the mixture of lithium (20 mmol) and naphthalene $(2 \mathrm{mmol})$ in $10 \mathrm{~mL}$ of freshly distilled THF was added $10 \mathrm{mmol}$ of zinc chloride dissolved in 10 $\mathrm{mL}$ of THF via a cannula at rt. And then the resulting mixture was allowed to stir for $1 \mathrm{~h}$. After settled-down at room temperature, the supernatant was cannulated off and then the resulting black powder was washed with THF $(20 \mathrm{~mL} \times 2)$. Added 20 $\mathrm{mL}$ of fresh THF to the slurry and then used for the following reactions.

Preparation of 2,4-Difluorophenylzinc Bromide (1). A 25 $\mathrm{mL}$ round-bottomed flask was charged with active zinc $(0.25 \mathrm{~g}$, $37.5 \mathrm{mmol}$ ) in $20 \mathrm{~mL}$ of THF. 1-Bromo-2,4-difluorobenzene $(0.48 \mathrm{~g}, 25 \mathrm{mmol})$ dissolved in $10 \mathrm{~mL}$ of THF was then added into the flask via a cannula while being stirred at room temperature. After the addition was completed, the resulting mixture was stirred at room temperature for $3 \mathrm{~h}$. The oxidative addition was monitored by GC analysis of the reaction mixture. After being settled down overnight at room temperature, the supernatant (organozinc solution) was used.

Preparation of Biphenyl-4-ylzinc Bromide (2). A $25 \mathrm{~mL}$ round-bottomed flask was charged with active zinc $(0.65 \mathrm{~g}, 100$ $\mathrm{mmol})$ in $10 \mathrm{~mL}$ of THF. 4-Bromobiphenyl ( $0.58 \mathrm{~g}, 25 \mathrm{mmol})$ dissolved in $10 \mathrm{~mL}$ of THF was then added into the flask via a cannula while being stirred at room temperature. After the addition was completed, the resulting mixture was stirred at refluxing temperature for $2 \mathrm{~h}$. The oxidative addition was monitored by GC analysis of the reaction mixture. After being settled down overnight at room temperature, the supernatant (organozinc solution) was used.

Preparation of 2',4'-Difluoro-4-hydroxybiphenyl-3-carboxylic Acid (Diflunisal). In a $25 \mathrm{~mL}$ round-bottomed flask, Pd (OAc) 2 (0.02 g, 2 mol \%), SPhos (0.08 g, 4 mol \%) and 5-bromosalicylate $(0.58 \mathrm{~g}, 2.5 \mathrm{mmol})$ were placed. Next, $6 \mathrm{mmol}$ of 1 $(0.5 \mathrm{M}$ in THF, $12 \mathrm{~mL})$ was added into the flask at room temperature. The resulting mixture was stirred at room temperature overnight. Quenched with saturated $\mathrm{NH}_{4} \mathrm{Cl}$ solution, then extracted with ether $(30 \mathrm{~mL} \times 3)$. Combined organics were washed with saturated $\mathrm{NaHCO}_{3}, \mathrm{Na}_{2} \mathrm{~S}_{2} \mathrm{O}_{3}$ solution and brine. Dried over anhydrous $\mathrm{MgSO}_{4}$. A flash column chromatography (5\% EtOAc/ $95 \%$ Heptane) gave $0.63 \mathrm{~g}$ of $1 \mathrm{a}$ as a beige solid in $95 \%$ isolated yield. mp $98-99^{\circ} \mathrm{C} .{ }^{1} \mathrm{H} \mathrm{NMR}\left(\mathrm{CDCl}_{3}, 500 \mathrm{MHz}\right) \delta 10.83(\mathrm{~s}, 1 \mathrm{H})$, $7.97(\mathrm{~s}, 1 \mathrm{H}), 7.59$ (d, $J=5.0 \mathrm{~Hz}, 1 \mathrm{H}), 7.36(\mathrm{q}, J=5.0 \mathrm{~Hz}, 1 \mathrm{H})$, $7.05(\mathrm{~d}, J=10 \mathrm{~Hz}, 1 \mathrm{H}), 6.88-6.96(\mathrm{~m}, 2 \mathrm{H}),{ }^{13} \mathrm{C} \mathrm{NMR}\left(\mathrm{CDCl}_{3}\right.$, 
$125 \mathrm{MHz}) \delta 170.60,161.39,136.39,131.30,131.22,130.36$, $126.27,118.09,112.64,111.92,111.75,104.62,104.60,52.65$; MS (EI) $m / z$ (\%) 264 (50) $\left[\mathrm{M}^{+}\right], 232$ (100), 204 (45), 175 (40). A typical hydrolysis afforded the corresponding acid $\mathbf{1 b}$ (Diflunisal) in $90 \%$.

Copper-catalyzed Coupling Reaction of 3; Preparation of 4-(Biphenyl-4-yl)-4-oxobutanoic Acid (Fenbufen). In a $25 \mathrm{~mL}$ round-bottomed flask, $\mathrm{CuI}(0.05 \mathrm{~g}, 10 \mathrm{~mol} \%), \mathrm{LiBr}(0.04 \mathrm{~g}$, $20 \mathrm{~mol} \mathrm{\%}$ ) and $5.0 \mathrm{~mL}$ of 3-ethoxy-3-oxopropylzinc bromide 3 (0.5 M in THF, $2.5 \mathrm{mmol})$ were placed. Cooled down to $0{ }^{\circ} \mathrm{C}$ using an ice-bath. Next, 4-Biphenylcarbonyl chloride $(0.50 \mathrm{~g}$, $2.3 \mathrm{mmol}$ ) was added into the flask at $0{ }^{\circ} \mathrm{C}$. After the addition was completed, the ice-bath was removed to warm-up room temperature while being stirred. The resulting mixture was stirred at room temperature for $4 \mathrm{~h}$. Quenched with saturated $\mathrm{NH}_{4} \mathrm{Cl}$ solution, then extracted with ether $(30 \mathrm{~mL} \times 3)$. Combined organics were washed with saturated $\mathrm{NaHCO}_{3}, \mathrm{Na}_{2} \mathrm{~S}_{2} \mathrm{O}_{3}$ solution, $10 \% \mathrm{NH}_{4} \mathrm{OH}$ solution and brine. Dried over anhydrous $\mathrm{MgSO}_{4}$. A flash column chromatography (5\% EtOAc/95\% Heptane) gave $2 \mathrm{a}$ as a beige solid in $65 \%$ isolated yield. mp $94-97^{\circ} \mathrm{C}$. A typical hydrolysis afforded the corresponding acid (Fenbufen) as an off-white solid in $93 \% .{ }^{1} \mathrm{H}$ NMR $\left(\mathrm{CDCl}_{3} / \mathrm{DMSO}-d_{6}, 500\right.$ MHz) $\delta 10.82$ (br s, 1H), $8.06(\mathrm{~d}, J=10 \mathrm{~Hz}, 2 \mathrm{H}), 7.70$ (d, $J=$ $10 \mathrm{~Hz}, 2 \mathrm{H}), 7.62(\mathrm{~d}, J=10 \mathrm{~Hz}, 2 \mathrm{H}), 7.48(\mathrm{t}, J=10 \mathrm{~Hz}, 2 \mathrm{H})$, $7.41(\mathrm{t}, J=10 \mathrm{~Hz}, 1 \mathrm{H}), 3.33(\mathrm{t}, J=5 \mathrm{~Hz}, 2 \mathrm{H}), 2.75$ ( t,$J=5 \mathrm{~Hz}$, $2 \mathrm{H}) ;{ }^{13} \mathrm{C} \mathrm{NMR}\left(\mathrm{CDCl}_{3} / \mathrm{DMSO}-d_{6}, 125 \mathrm{MHz}\right) \delta 197.49,174.36$, $145.24,139.33,134.99,128.62,128.57,128.25,127.90,126.83$, 33.15, 27.79.

Preparation of 2-(Biphenyl-4-yl)acetic Acid (Felbinac). In a $25 \mathrm{~mL}$ round-bottomed flask, $\mathrm{Pd}\left(\mathrm{PPh}_{3}\right)_{4}(0.06 \mathrm{~g}, 1 \mathrm{~mol} \%)$ and $10 \mathrm{~mL}$ of 4-phenylbenzylzinc chloride 4 ( $0.5 \mathrm{M}$ in THF, $5 \mathrm{mmol})$ were placed. Next, ethyl chloroformate $(1.08 \mathrm{~g}, 10 \mathrm{mmol})$ was added into the flask at room temperature. The resulting mixture was stirred at room temperature overnight. Quenched with saturated $\mathrm{NH}_{4} \mathrm{Cl}$ solution, then extracted with ether $(30 \mathrm{~mL} \times 3)$. Combined organics were washed with saturated $\mathrm{NaHCO}_{3}$, $\mathrm{Na}_{2} \mathrm{~S}_{2} \mathrm{O}_{3}$ solution and brine. Dried over anhydrous $\mathrm{MgSO}_{4}$. A flash column chromatography ( $2 \%$ EtOAc/ $98 \%$ Heptane) gave $0.80 \mathrm{~g}$ of $\mathbf{3 a}$ as colorless oil in $67 \%$ isolated yield.

A Typical Hydrolysis Procedure. To a $50 \mathrm{~mL}$ round-bottomed flask was added $0.80 \mathrm{~g}(3.3 \mathrm{mmol})$ of $\mathbf{3} \mathbf{a}$ and then dissolved in $10 \mathrm{~mL}$ of THF. Next, $\mathrm{KOH}$ solution $(0.20 \mathrm{~g}$, dissolved in $10 \mathrm{~mL}$ of $\mathrm{H}_{2} \mathrm{O}$ ) was added. The resulting mixture was heated to reflux for $30 \mathrm{~min}$. Cooled down then, the mixture was extracted with ether to remove organic residues. The resulting basic solution was acidified with $3 \mathrm{M} \mathrm{HCl}$ solution affording the corresponding acid 3b (Felbinac) as a white solid in 94\% isolated yield. ${ }^{1} \mathrm{H} \mathrm{NMR}\left(\mathrm{CDCl}_{3} / \mathrm{DMSO}-d_{6}, 500 \mathrm{MHz}\right) \delta 10.85$ (br s, $\left.1 \mathrm{H}\right), 7.50-$ $7.62(\mathrm{~m}, 4 \mathrm{H}), 7.40-7.45(\mathrm{~m}, 2 \mathrm{H}), 7.30-7.38(\mathrm{~m}, 3 \mathrm{H}), 3.64(\mathrm{~s}$, $2 \mathrm{H}) ;{ }^{13} \mathrm{C} \mathrm{NMR}\left(\mathrm{CDCl}_{3} / \mathrm{DMSO}-d_{6}, 125 \mathrm{MHz}\right) \delta 174.02,140.82$,
$139.77,133.61,129.83,128.75,127.20,127.01,40.39 ;$ MS (EI) $\mathrm{m} / z(\%) 212(49)\left[\mathrm{M}^{+}\right], 167$ (100), 115 (10).

Acknowledgments. The present research was conducted by the research fund of Dankook university in 2010.

\section{References}

1. (a) Review of organozinc reagents; Knochel, P.; Calaza, M. I.; Hupe, E. In Metal-Catalyzed Cross-Coupling Reactions, 2nd ed.; de Meijere, A., Diederich, F., Eds.; Wiley-VCH: Weinhelm, Germany, 2004; Vol. 1, Chapter 11. (b) E. Nakamura, Organozinc Chemistry in Organometallics in Synthesis: A manual, 2nd ed.; Schlosser, M., Ed.; Wiley: Chichester, 2002, 579.

2. (a) Kim, S. H.; Rieke, R. D. Tetrahedron 2010, 66, 3135. (b) Kim, S. H.; Rieke, R. D. Tetrahedron Lett. 2010, 51, 2657.

3. (a) Horton. D.; Bourne, D.; Smythe, M. Chem. Rev. 2003, 103, 893. (b) Hannah, J.; Ruyle, W. V.; Jones, H.; Matzuk, A. R.; Kelly, K. W.; Witzel, B. E.; Holtz, W. J.; Houser, R. A.; Shen, T. Y. J. Med. Chem. 1978, 21, 1093.

4. (a) Cepanec, I. Synthesis of Biaryls; Elsevier: Amsterdam, 2004, 17. (b) Lindsey, A.; Jeskey, H. Chem. Rev. 1957, 57, 583 (c) Jones, H.; Houser, R. W.; Utne, T.; Jobson, R. B.; Lovell, A. V. U.S. Patent 4,225,730. 1980.

5. Giordiano, C.; Coppi, L.; Minisci, F. U.S. Patent 5,312,975, 1994.

6. (a) Kylmala, T.; Tois, J.; Xu, Y.; Franzen, R. Cen. Eur. J. Chem. 2009, 7, 818. (b) DeVasher, R. B.; Moore, L. R.; Shaughnessy, K. H. J. Org. Chem. 2004, 69, 7919.

7. Jeong, N.; Lee, S. J.; Choi, K. H.; Chung, S. Bull. Korean Chem. Soc. 2000, 21, 165.

8 . For the general procedure for the preparation of organozinc reagents, see; Guijarro, A.; Rosenberg, D. M.; Rieke, R. D. J. Am. Chem. Soc. 1999, 121, 4155, references cited therein.

9. Srinivas, Ch.; Haricharan Raju, C. M.; Acharyulu, P. V. R. Org. Process Res. Dev. 2004, 8, 291 and references cited therein.

10. (a) Child, R. G.; Osterberg, A. C.; Sloboda, A. E.; Tomcufcik, A. S. J. Pharma. Sci. 2006, 66, 466. (b) Lu, G.; Franzen, R.; Zhang, Q.; $\mathrm{Xu}, \mathrm{Y}$. Tetrahedron Lett. 2005, 46, 4255. (c) Zohrabi-Kalantari V.; Link, A. Arch. Pharm. Phar. Med. Chem. 2004, 337, 546. (d) Castillo, R.; Suarez-Herrera, M.; Aparicio, M.; Hernandez-Lui, F.; Hernandez, A. Org. Preparations and Procedures Int. 1995, 27 , 550.

11. For a representative result of carbon-oxygen bond cleavage in THF; see, Kang, J.; Kim. S. H. Bull. Korean Chem. Soc. 2000, 21, 611.

12. Selected examples, see; (a) Kim, S. H.; Rieke, R. D. J. Org. Chem. 2000, 65, 2322. (b) van den Anker, T. R.; Harvey, S.; Raston, C. L. J. Organomet. Chem. 1995, 502, 35. (c) Chupak, L. S.; Wolkowski, J. P.; Chantigny, Y. A. J. Org. Chem. 2009, 74, 1388. (d) Metzger, A.; Schade, M. A.; Knochel, P. Org. Lett. 2008, 10, 1107.

13. (a) Mizushima, Y.; Fujii, M.; Takei, H. U. S. Patent 3,784,704, 1974. (b) Blicke, F. F.; Grier, N. J. Am. Chem. Soc. 1943, 65, 1725.

14. (a) Vassylyev, O.; Chen, J.; Panarello, A. P.; Khinast, J. G.; Tetrahedron Lett. 2005, 46, 6865. (b) Jiang, X.; Sclafani, J.; Prasad, K.; Repic, O.; Blacklock, T. J. Org. Process Res. Dev. 2007, 11, 769. (c) Hooz, J.; Bridson, J. N.; Calzada, J. G.; Brown, H. C.; Midland, M. M.; Levy, A. B. J. Org. Chem. 1973, 28, 2574. 